Military Technical College

Kobry El-Kobbah,

Cairo, Egypt

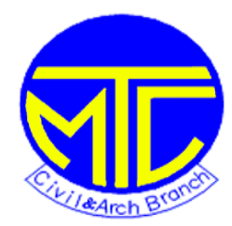

$9^{\text {th }}$ International Conference on Civil and Architecture Engineering

ICCAE-9-2012

\title{
ASSESSMENT OF LIQUEFACTION POTENTIAL IN SINAI, EGYPT
}

\author{
H. M. HUSSEIN* AND M.H. RABIE**
}

\begin{abstract}
Sinai Peninsula has a triangular shape between the African and Arabian Plates and bounded from the western and eastern borders by the Gulf of Suez and Gulf of Aqaba-Dead Sea rift systems, respectively. It has been affected by strong and destructive earthquakes, and moderate earthquakes through its history. Due to the damage distributions observed during these earthquakes, it became necessary to construct the seismic mapping for Sinai based on the available data (including SPT and CPT results) that have been collected from site investigations of some locations. The factors of safety against liquefaction for some locations in Sinai are accurately computed in this work conducted herein this paper. This paper presents an important contribution for constructing a map for Sinai representing the minimum safety factors against liquefaction and hence the liquefaction susceptibility. It is concluded that, Sharm El-Sheikh zone located at the southern tip of Sinai generally represents the most critical zone in Sinai, regarding the seismicity effect in case a high seismic local magnitude $(\mathrm{M}=7.2)$ is applied.
\end{abstract}

\section{KEYWORDS:}

Earthquakes, geology, liquefaction, mapping, Sinai, Egypt.

\section{INTRODUCTION}

Liquefaction and related phenomena have been responsible for tremendous amounts of damage in the history of earthquakes around the world. Structures on top of loose sand deposits that have liquefied during an earthquake may sink or fall over, and buried tanks may float to the surface when the loose sand liquefies [1].

In many cases, damages of structures on loose sand layers have occurred by differential settlement of the foundations caused by ground shaking combined with natural variability of subsoil. In saturated very loose to loose silty sand soils seismic shocks may cause unacceptable shear deformations.

\footnotetext{
* Lecturer of Geotechnical Eng., Civil Eng. Dept., Helwan University, Cairo, Egypt

** Associated Professor of Geotechnical Eng., Civil Eng. Dept., Helwan University, Cairo, Egypt
} 
These deformations may be the result of shear stresses exceeding the strength of a soil that softens beyond peak shear strength. The high shear deformations and the reduced shear strength may also be a consequence of the buildup of high pore water pressure generated by seismic shaking. With limited drainage, the cyclic shear stresses can produce a progressive build of pore water pressure that significantly reduces the shear strength of the soil. For practical purposes, the effective stresses after several cycles of shear strain may ultimately be reduced to zero leading to liquefaction. The longer and the stronger the cyclic shear stress application from the earthquake, the longer the state of liquefaction persists. Likewise, if the liquefied soil is confined by an upper and a lower clay layer, then it will take longer for the excess pore water pressures to dissipate by the flow of water from the liquefied soil. After the liquefaction process is complete, the soil may be in a somewhat denser state.

The typical subsurface soil condition that is susceptible to liquefaction is loose sand, which has been newly deposited or placed, with a groundwater table near ground surface. During an earthquake, the application of cyclic shear stresses induced by the propagation of shear waves causes the loose sand to contract, resulting in an increase in pore water pressure. Because seismic shaking occurs so quickly, cohesionless soil is subjected to an undrained loading (total stress analysis). The increase in pore water pressure causes an upward flow of water to the ground surface where it emerges in the form of mud spouts or sand boils. The development of high pore water pressures due to the ground shaking and the upward flow of water may turn the sand into a liquefied condition, which has been termed liquefaction. For this state of liquefaction, the effective stress is zero, and the individual soil particles are released from any confinement, as if the soil particles were floating in water [2].

After the soil has liquefied, the excess pore water pressure will start to dissipate. The length of time that the soil will remain in a liquefied state depends on two main factors:

a. Duration of the seismic shaking from the earthquake; and

b. Drainage conditions of the liquefied soil.

\section{SEISMICITY OF SINAI}

The Red Sea rift zone is an area of medium to high seismic hazard with a numerous number of medium- to high-magnitude earthquakes recorded historically. Sinai and its surrounding area are classified as part of the unstable African shelf in the tectonic divisions of Egypt [3].

Sinai experienced the largest Egyptian earthquake with moment magnitude (M) 7.2 in November 1995 in the Gulf of Aqaba, $350 \mathrm{~km}$ from Cairo which is larger than Dahshour earthquake of (M) 5.9 in October, 1992, and Aswan earthquake of (M) 6.2 in November, 1981.

Table 1 presents some of the earthquakes as well as their locations and magnitudes that occurred in Egypt since 2200 B.C.

Table 1. Some earthquakes' locations and magnitudes in Egypt 


\begin{tabular}{|c|c|c|c|c|c|}
\hline Date & $\begin{array}{c}\text { Latitude } \\
\text { (N) }\end{array}$ & $\begin{array}{c}\text { Longitude } \\
\text { (E) }\end{array}$ & Location & Magnitude & Reference \\
\hline 2200 B.C. & 30.5 & 31.7 & & 5.4 & \multirow{4}{*}{$\begin{array}{c}\text { Maamoun, et al, } \\
1984 \text { [4] }\end{array}$} \\
\hline 742 & 29.44 & 32.53 & South Suez & & \\
\hline $\begin{array}{c}\text { August } 8, \\
1303\end{array}$ & 29.9 & 31 & Fayium & & \\
\hline $\begin{array}{c}\text { October } 2, \\
1698\end{array}$ & 32 & 30.5 & $\begin{array}{c}\text { Rosetta } \\
\text { area }\end{array}$ & 5.3 & \\
\hline $\begin{array}{c}\text { March 31, } \\
1969\end{array}$ & 27.6 & 33.9 & $\begin{array}{l}\text { Shadwan } \\
\text { Island }\end{array}$ & 6.3 & \multirow[b]{2}{*}{$\begin{array}{c}\text { Qubaissy, et al, } \\
1981 \text { [5] }\end{array}$} \\
\hline $\begin{array}{c}\text { November } \\
14,1981\end{array}$ & 23.55 & 32.55 & $\begin{array}{c}\text { Wadi } \\
\text { Kalabsha } \\
\text { and Gabnal }\end{array}$ & 5.6 & \\
\hline $\begin{array}{c}\text { November } \\
22,1995\end{array}$ & 28.62 & 34.66 & $\begin{array}{l}\text { Gulf of } \\
\text { Aqaba }\end{array}$ & 7.2 & $\begin{array}{c}\text { El-Sayed, et al, } \\
1999 \text { [6] }\end{array}$ \\
\hline
\end{tabular}

Sinai is characterized by unprecedented development with tens of new mini-towns and tourist resorts, especially at the shoreline in South Sinai, in addition to different natural resources. The aim of the current study is to assess the seismic hazard for Sinai. Revised earthquake catalogues for Sinai and its surroundings, from 112 B.C. to 2006 A.D. with magnitude equal to or greater than 3.0, are used to calculate seismic hazard in the region of interest between $27^{\circ} \mathrm{N}$ and $31.5^{\circ} \mathrm{N}$ and $32^{\circ} \mathrm{E}$ and $36^{\circ} \mathrm{E}$. The highest hazard is found in the Gulf of Aqaba with maximum spectral accelerations of $356 \mathrm{~cm} \cdot \mathrm{sec}^{-2}$ at a period of $0.22 \mathrm{~s}$ for a return period of 475 years [7].

It is concluded that a level of PGA of about $0.175 \mathrm{~g}$ is a conservative value recommended for design. The possible deterministic earthquake scenarios for the area are discussed. These are used to select recorded ground-motion accelerations from seismotectonic environments similar to the South Sinai area [8].

In Sinai there are no mapped faults younger than Miocene ( 7 to 26 million years). These faults occur in late Miocene rocks of the Narmarica formation. The activity or date of last movement of these faults was not cited in the references. Historic earthquake epicenter locations do not coincide with these mapped faults. It is probable that faults exist but are covered by sediments and the Mediterranean Sea [3].

\section{REGIONAL GEOLOGY}

Northern Sinai forms a distinct geomorphologic and structural unit, which is characterized by a large number of northern trending elliptical anticlines and intervening synclinal depressions [3]. These anticlines and synclines are breached by erosion and are fractured along lines that run more or less parallel to the axes of anticlines. Geomorphologically, this part of Sinai forms what terms as "La région des domes" [6]. It is in a radical contrast with the plateau character of central Sinai, which is made of horizontal Cretaceous and Eocene strata. 
The principal structural features of this part of Sinai are forming part of a broad synclinal area, which covers both the TIH plateau and northern Sinai. In the northern Sinai area including Arish, these synclinal structures are obscured by a series of superimposed structures manifested in a number of elongated hog-backed massifs running suddenly out of the chalk plains of central Sinai. Each of these massifs is an asymmetrical outline with it axis running approximately north to northeast [9].

Investigations indicate that the north region of Sinai comprises three structural units. These three structural units are outlined hereinafter from north to south and are developed as follows [10]:

1. The Mediterranean fore-shore area. This belt covers the triangular area extending between the Mediterranean coastline and the line between the Bitter Lake and Rafah, and covers an area of about $8000 \mathrm{~km}^{2}$. Topographically this area is of low relief and comprises the coastal areas with a complex of parallel coastal dunes and offshore bars in the center enclosing the Bardawil Lake. By analogy with similar gravity anomalies at some locations drilled to the west of the Bitter Lake, it is possible that this area may be transversed by a number of northeast structures similar in their geological history to those exposed in the south of the north region.

2. North Sinai strongly folded area (frontal folds). This belt covers $13000 \mathrm{~km}^{2}$ in area and extends in the northeast direction to the south of the Mediterranean foreshore area. This portion of Sinai is characterized by the presence of restively pronounced mountain ranges oriented in a northeast direction. This represents elevated anticlinal structures that are separated by synclinal areas that occupy the modern topographies. Longitudinal faults are rare, though they become well pronounced in Maghara and Giddi.

3. The North Sinai fractured area (Hingebelt). This belt covers an area of about $4000 \mathrm{~km}^{2}$. It extends from Mitla pass to east of Suez, to Arif El-Naga on the eastern border of Sinai, and farther into Negev. The area is characterized by a large number of longitudinal faults that affect the relief and morphology of the belt.

The core of Sinai peninsula, situated near its southern end, consists of an intricate complex of high and very rugged igneous and metamorphic mountains. The core of the peninsula has a pseudo-Appalachian relief and shows all the signs of youthful physiography. It is dissected by numerous incised wadis that are everywhere showing signs of dowcutting.

Sharm El Sheikh is located in the lower part of south Sinai at the Red sea coast. Sharm el-Sheikh is overlooking the Straits of Tirana at the mouth of the Gulf of Aqaba. It stretches for about $40 \mathrm{~km}$ along the seashore, and it does not reach far into the surrounding desert. Sharm El Sheikh geology stems from the following eras: Precambrian, lower Miocene, Cretaceous, Pliocene and Quaternary. However, the most important part is the coastal zone geology. The rocks exposed north and west of Sharm El-Sheikh forming the northern part of the rocky land at the coastal plain. These outcrops are composed mainly of alternate beds of marl and sandstones with fossillerferous carbonate beds in the lower part. Pliocene rocks are exposed along the coastal plain from Ras Mohammed to Ras Nusrani forming the rocky lands of the coast. They comprise dark colored conglomerates that alternate with sandstone beds [11]. 


\section{ASSESSMENT OF LIQUEFACTION POTENTIAL}

\subsection{General}

The liquefaction assessment for the main cities (Arish, Kherba, Rummanah, Abu Zenima and Sharm El-Sheikh) is studied. The cities under study are shown in Fig. 1.

In order to assess the variation of the geotechnical formation for the different studied locations, the soil profiles and ground water levels had been presented as shown in Fig. 2.

Contrary to the recommendations of the Egyptian seismic code, the level of excitation for low-rise structures is significant and should not be ignored.

The potential for liquefaction increases as the earthquake intensity and duration of shaking increase. Those earthquakes that have the highest magnitude will produce both the largest ground acceleration and the longest duration of ground shaking. Although data are sparse, there would appear to be a shaking threshold that is needed to produce liquefaction. These threshold values are a peak ground acceleration $\mathrm{a}_{\max }$ of about $0.10 \mathrm{~g}$ and local magnitude ML of about 5 [2].

Regarding the seismic conditions of Sinai, the peak ground acceleration shall be considered $0.2 \mathrm{~g}$ with magnitude $\mathrm{M}=7.2$. The assessment of liquefaction potential shall be calculated at different depths taking into consideration the ground water level at different locations.

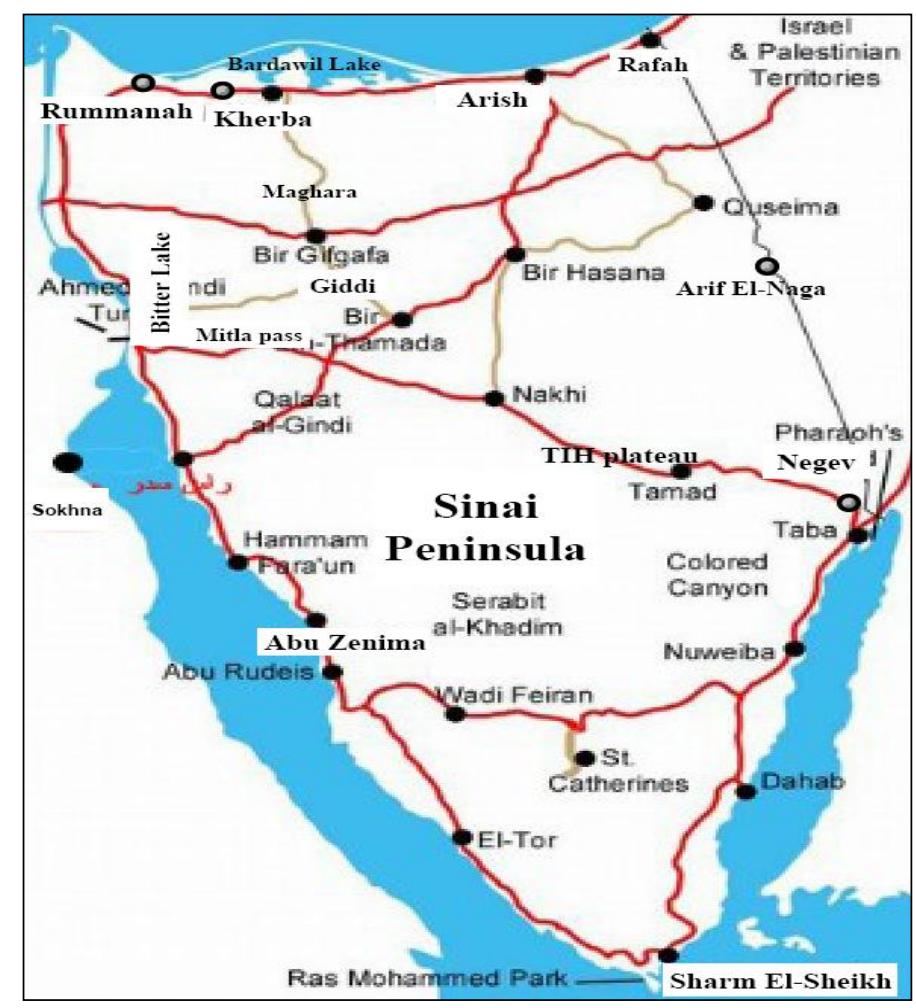

Fig. 1. Sinai Peninsula and its main cities. 
Proceedings of the $\mathbf{9}^{\text {th }}$ ICCAE-9 Conference, 29-31 May, 2012 


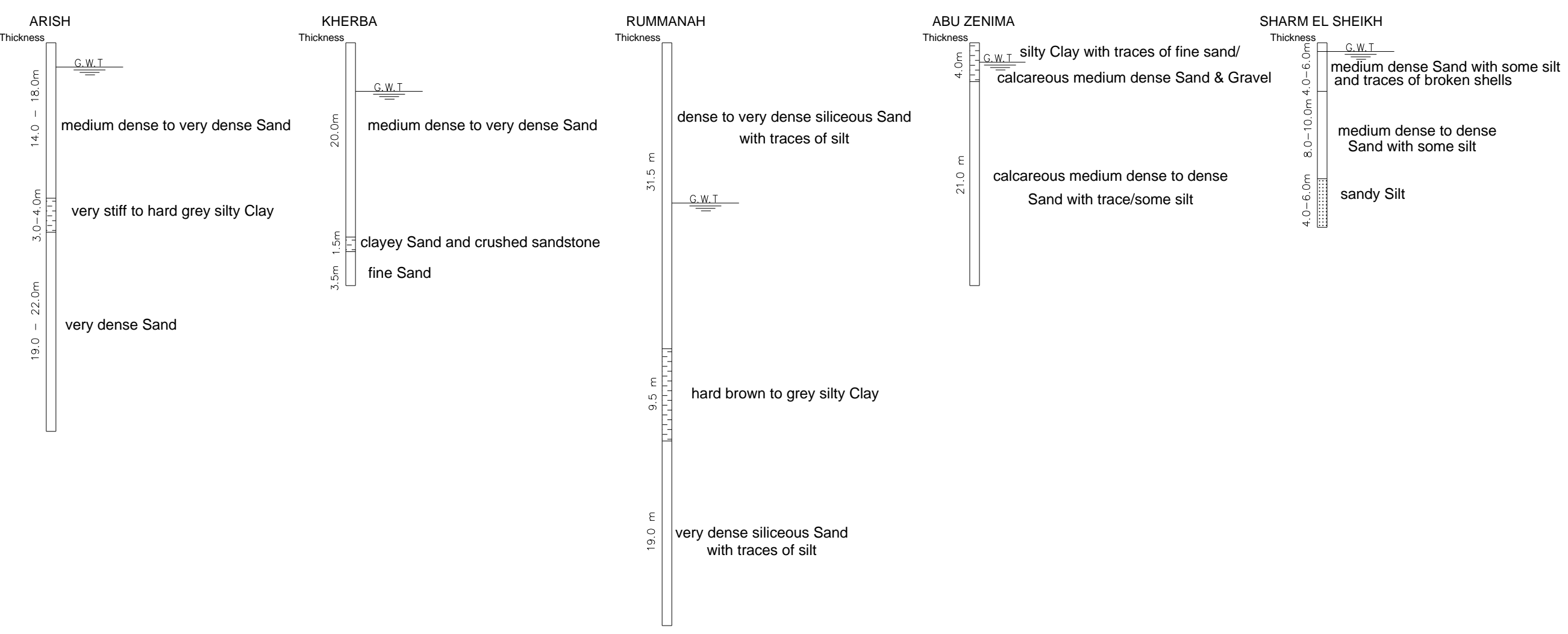


Fig. 2. Soil profiles and ground water levels of the case studies used 


\subsection{Assessment Methodology}

\subsubsection{Using SPT results}

The most common type of analysis to determine the liquefaction potential is to use the Standard Penetration Test (SPT) [12 \& 13]. The analysis is based on the simplified method proposed by [14].

The procedure of evaluating the cyclic liquefaction potential of a sand deposit subjected to earthquake shaking using SPT results has been applied. This approach evaluates the stresses included by specified maximum acceleration at the ground surface and the liquefaction resistance using field penetration test results, allowing for determination of factor of safety against liquefaction.

The ratio of the average cyclic shear stresses CSR developed on the surface of sand as a result of the cyclic earthquake loading to the initial vertical effective stress acting on the sand layer before the earthquake shaking was presented by [14] in following formula:

$$
C S R=\frac{\tau_{a v r}}{\sigma_{o}^{\prime}}=\frac{0.65 a_{\max } \sigma_{v} r_{d}}{C_{m} g \sigma_{o}^{\prime}}
$$

where: $\mathrm{a}_{\max }=$ maximum acceleration at the ground surface, $\sigma_{\mathrm{v}}=$ total overburden pressure, $\sigma_{\mathrm{o}}{ }^{\prime}$ $=$ effective overburden pressure, $\mathrm{C}_{\mathrm{m}}=$ Correlation factor for different magnitude of earthquake (as given in Table 2), $r_{d}=$ stress reduction factor $=1-0.0076515 Z$ (for $Z<9.15$ $\mathrm{m}$ ), $\mathrm{r}_{\mathrm{d}}=1.174-0.0267 \mathrm{Z}$ (for $9.15<\mathrm{Z}<23 \mathrm{~m}$ ), $\mathrm{r}_{\mathrm{d}}=0.744-0.008 \mathrm{Z}$ (for $23<\mathrm{Z}<30 \mathrm{~m}$ ) and $\mathrm{r}_{\mathrm{d}}=0$ (for $\mathrm{Z}>30 \mathrm{~m}$ ), $\mathrm{Z}=$ depth in meters.

Table 2. Variation of Correlation factor with earthquake magnitudes

\begin{tabular}{|c|c|c|c|c|c|c|}
\hline Earthquake Magnitude M & 5.5 & 6 & 6.5 & 7 & 7.5 & 8 \\
\hline $\mathrm{C}_{\mathrm{m}}$ & 2.86 & 2.2 & 1.69 & 1.3 & 1 & 0.67 \\
\hline
\end{tabular}

On the basis of the standard penetration test results, the cyclic shear resistance ratio CRR resisting liquefaction is calculated using the work proposed by [15]. By adopting the chart shown in Fig. 3 and the number of blows in SPT tests after corrections, the value of CRR can be concluded. 


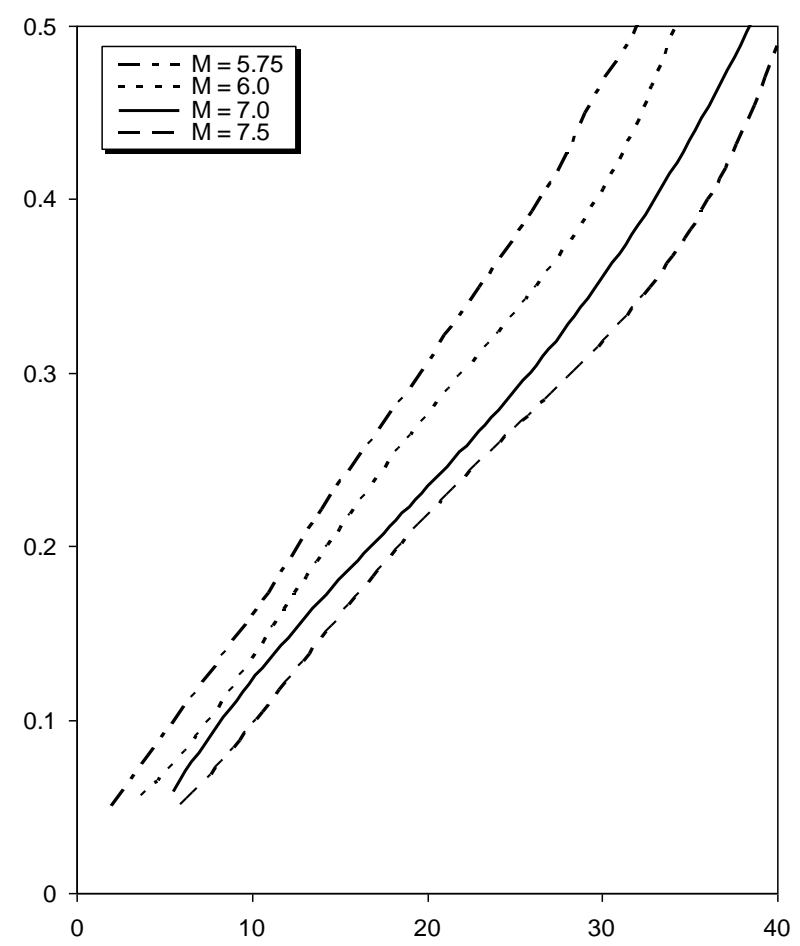

Modifed Penetration Resistance N ( blows/ft )

Fig. 3. Evaluating the liquefaction resistance using SPT

The factor of safety against liquefaction (F.S) is calculated as follows:

$$
F . S=C R R / C S R
$$

The higher the factor of safety, the more resistant the soil is to liquefaction. However, soil that has a factor of safety slightly greater than 1.0 may still liquefy during an earthquake. A minimum factor of safety of 1.25 is required according to EUROCODE [16].

\subsubsection{Using CPT results}

While SPT has been widely used for many years, in many cases it may be more expedient to explore the variability of conditions within an extensive sand deposit using the static Cone Penetration Test (CPT). The main advantages of this procedure are to provide a continuous record of penetration resistance in any borehole, and it is less vulnerable to operator error than the SPT test.

Procedure of evaluating the cyclic liquefaction potential of a saturated sand deposit subjected to earthquake shaking using cone penetration test results can be summarized as follows:

- Calculation of Cyclic Stress Ratio CSR induced in the soil by an earthquake.

- Calculation of Cyclic Resistance Ratio CRR based on in-situ tests data from CPT tests. 
- Evaluation of the liquefaction potential by calculating the factor of safety against liquefaction where the factor of safety is defined as the ratio between CRR/CRS.

The calculation of the value of CRS shall be calculated using above Eq. (1), while the value of CRR shall be calculated based on the results of CPT.

Many methods have been developed to evaluate the value of CRR based on CPT data. Among these methods, two different techniques shall be implemented in the assessment of the liquefaction potential. The first one is Seed's method [17 \& 18], and the second one is Robertson's method [19] published in the Proceedings of NCEER workshop [20].

a) Seed's method

In this method, the first step is to correct the measured CPT tip resistance for overburden pressure as follow:

$$
q_{c i}=C q^{*} q_{c} \quad \text { where } \quad C q=\frac{1.8}{0.8+\frac{\sigma}{\sigma_{r e f}}}
$$

where $\sigma$ is the effective stress in $\mathrm{kPa}$, and $\sigma_{\text {ref }}$ is the atmospheric pressure $(100 \mathrm{kPa})$.

The second step is to correct the cone resistance for the fines content as follows [11]:

$$
q_{c i f}=q_{c i}+\Delta q_{c i}
$$

where: $\Delta q_{c i}$ is calculated from the percent of fines as shown in Fig. 4.

The third step is to calculate the value of $\mathrm{CRR}_{\mathrm{M}=7.5}$. This is done using the curves developed by [17] as shown in Fig. 5. It must be noticed that the use of these curves requires the value of $\mathrm{D}_{50}$.

\section{b) Robertson's method}

The main difference between this method and Seed's method is that the percent of fines is calculated by Robertson based on the readings of the CPT (cone and sleeve resistance) and this percent is used automatically in the correction for fines. This implies an iteration method to calculate the soil type behavior factor $\left(I_{c}\right)$, which is used for the classification of a soil based on both cone and sleeve resistance.

For liquefaction analysis, the computer software "Liquefy Pro" is used. This program is developed by Civil Tech software and it is based on the most recent publications of NCEER workshop.

The basic soil data required for liquefaction analysis by "Liquefy Pro" are the SPT data, the CPT data, the soil unit weight, the ground water level, the percent of fines and the value of 
$\mathrm{D}_{50}$. In addition, the basic earthquake data required are the earthquake acceleration and the earthquake magnitude $M$.

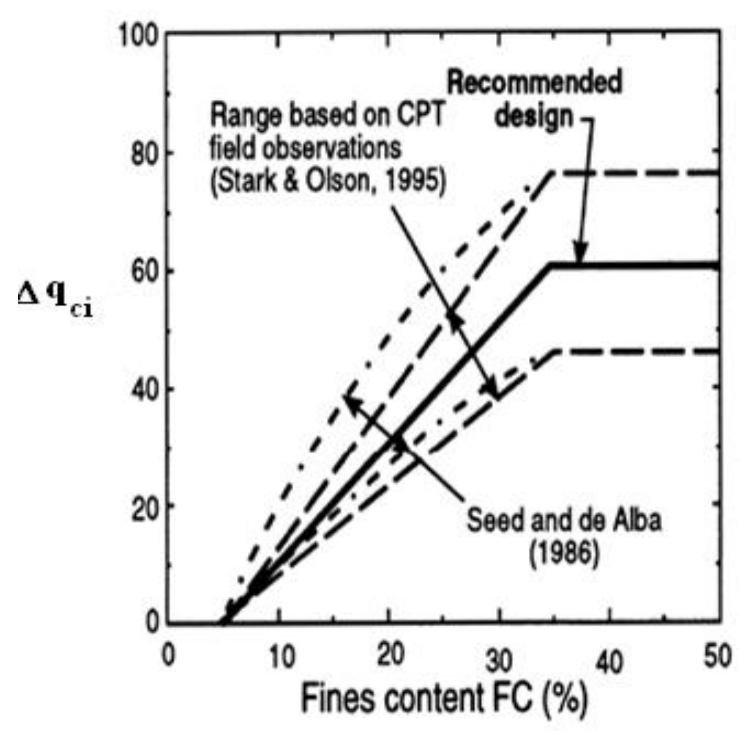

Fig. 4. Correction of cone resistance due to fines content

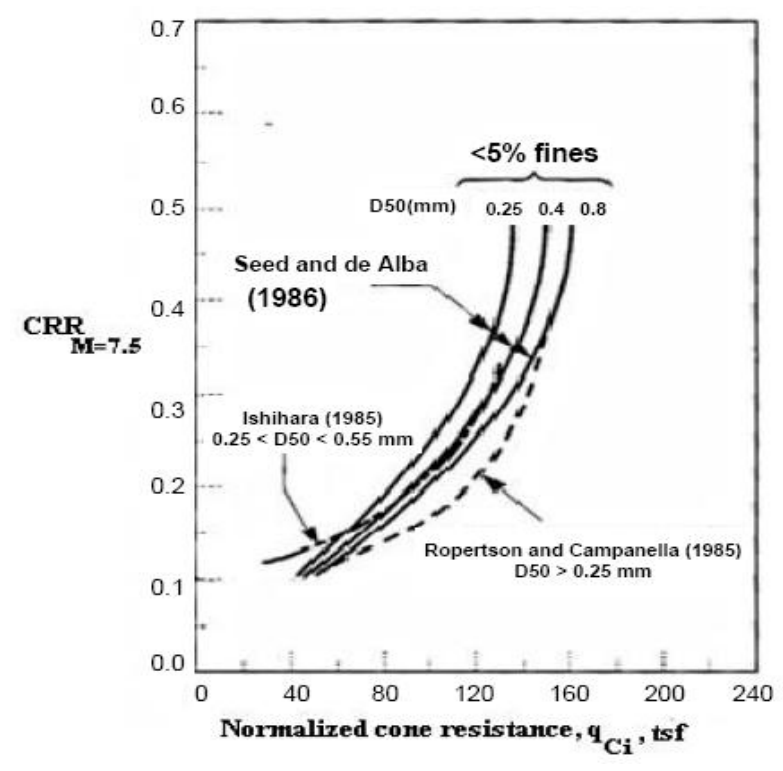

Fig. 5. Determination of Cyclic Resistance Ratio

\subsection{North Sinai Area}

Three locations in North Sinai area (Arish, Kherba and Rummanah cities) are studied. The Arish and Kherba are denoted as Site 1 and Site 2. The first studied location is extended from Biar El Ganadel West to El Sir area in the Southeast of Arish city. The total number of boreholes that have been carried out in this zone was 22 boreholes with depths ranging between $10 \mathrm{~m}$ and $40 \mathrm{~m}$. The soil condition along this site is composed of medium dense to very dense sand layer with a thickness ranging from 14 to $18 \mathrm{~m}$ (with measured $\mathrm{N}_{\mathrm{SPT}}$ ranging from 7 to over than 50 blows) followed by a very stiff to hard grey silty clay layer with a thickness ranging from 3 to $4 \mathrm{~m}$ followed by a very dense sand layer (with measured $\mathrm{N}_{\mathrm{SPT}}$ over than 50 blows) down to end of boreholes. The groundwater table was encountered at a depth of about $2.5 \mathrm{~m}$ below the ground surface.

The upper sand layer is yellow medium sand with traces/some silt. The percentages of sand and gravel are as given in Table 3 (average values):

Table 3. Percent of soil components and classification for the top sand layer of Arish city, Site 1

\begin{tabular}{|c|c|c|c|c|c|}
\hline \multirow{2}{*}{$\%$ Fines } & \multicolumn{3}{|c|}{ \% Sand } & \multirow{2}{*}{$\%$ Gravel } & \multirow{2}{*}{ USCS } \\
\cline { 2 - 4 } & Fine & medium & Coarse & & \\
\hline 7 & 18 & 62 & 13 & 0 & SP \\
\hline
\end{tabular}

The soil classification of these layers according Unified Soil Classification System (USCS) is SP in most cases. The result of the liquefaction analysis is represented in Fig. 6. 
The second studied location extends from Kherba to Arish road at $\mathrm{km} 70$. The soil along this site is composed of medium dense to very dense sand (with measured $\mathrm{N}_{\mathrm{SPT}}$ ranging from 12 to over than 50 blows) with a thickness of about $20.0 \mathrm{~m}$ followed by a clayey sand and crushed sandstone layer with a thickness of about $1.5 \mathrm{~m}$ followed by a fine sand layer down to the end of the boreholes $(25 \mathrm{~m})$. The groundwater table was encountered at a depth of about $5.0 \mathrm{~m}$ below the ground surface.

The upper sand layer is brown fine to medium with traces/some silt and the percentage of fines as well as the percentages of sand and gravel are shown in Table 4 (average values).

The soil classification of this layer according Unified Soil Classification System (USCS) is SP in most cases. Using the correlations in item 4.2.1, the factor of safety is more than 1.25 for all depths as shown in Fig. 7.

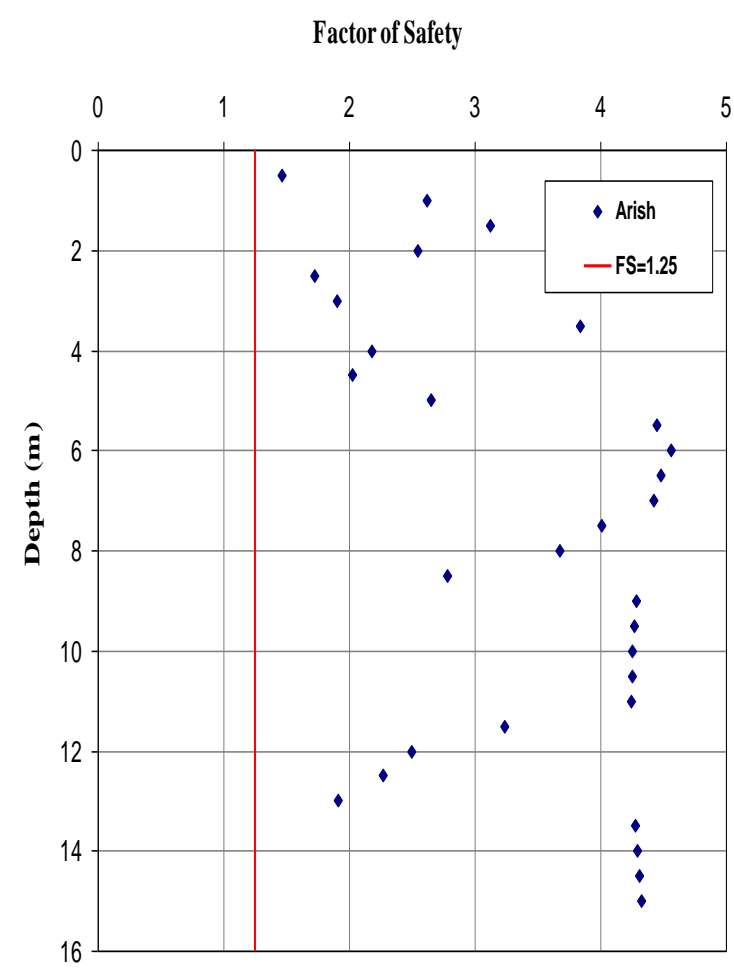

Fig. 6. Safety factors against liquefaction versus depth for Arish city - Site 1

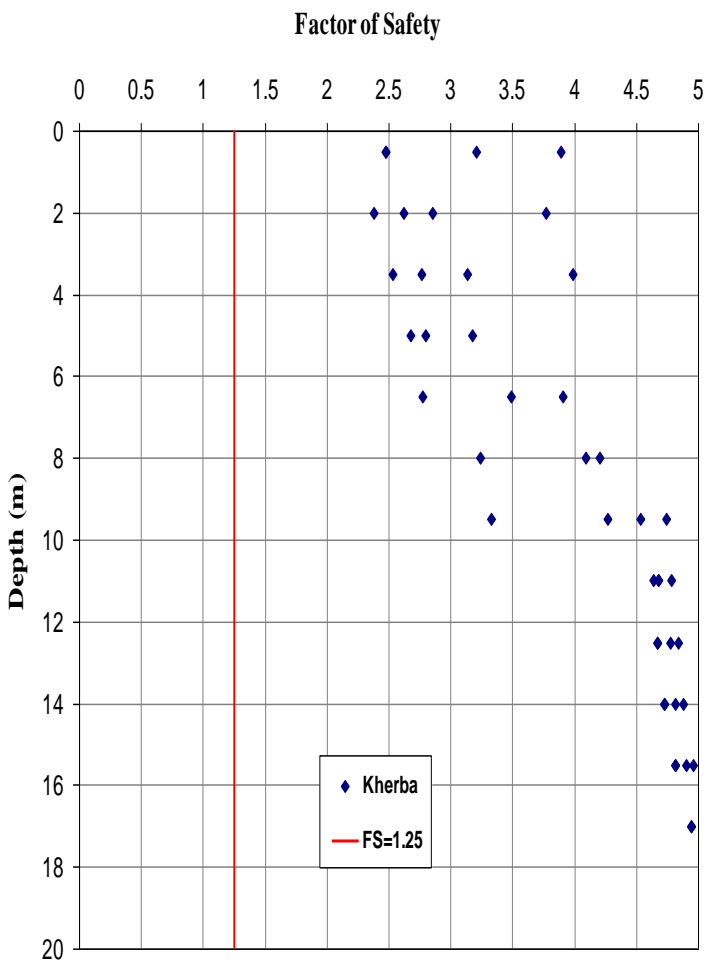

Fig. 7. Safety factors against liquefaction versus depth for Kherba city - Site 2

Table 4. Percent of soil components and classification for the top sand layer of Kherba city,

Site 2

\begin{tabular}{|c|c|c|c|c|}
\hline \multirow{2}{*}{$\%$ Fines } & \multicolumn{3}{|c|}{ \% Sand } & \multirow{2}{*}{ \% Gravel } \\
\cline { 2 - 4 } & Fine & medium & Coarse & \\
\hline 5 & 65 & 30 & 0 & 0 \\
\hline
\end{tabular}

\subsection{Rummanah City}


The studied site is an onshore gas plant which is located near Rummanah, north Sinai. Just two boreholes with depth of $60 \mathrm{~m}$ each have been excavated in this zone. The soil profile of this site is yellow to brown dense to very dense sand layer of siliceous origin with traces of silt with a thickness of $31.5 \mathrm{~m}$ (with measured $\mathrm{N}_{\mathrm{SPT}}$ ranging from 23 to over than 50 blows). This layer is followed by hard brown to grey silty clay with a thickness of $9.5 \mathrm{~m}$, followed by very dense yellow to brown sand layer of siliceous origin with traces of silt (with measured $\mathrm{N}_{\mathrm{SPT}}$ over than 50 blows) down to the end of the boreholes $(60 \mathrm{~m})$. The groundwater table was encountered at a depth of about $16.5 \mathrm{~m}$ below the ground surface.

To identify the properties of the upper sand layer, particle size distribution tests had been carried out and the percentage of fines was ranging from $4 \%$ to $12 \%$, while the percentage of sand was ranging from $96 \%$ to $88 \%$. According to the Unified Soil Classification System, the sand can be classified as SP-SM. The result of the liquefaction analysis is depicated in Fig. 8.

It is obvious from the calculations (using the correlations in item 4.2.1) that the factor of safety is more than 3.5 for all depths.

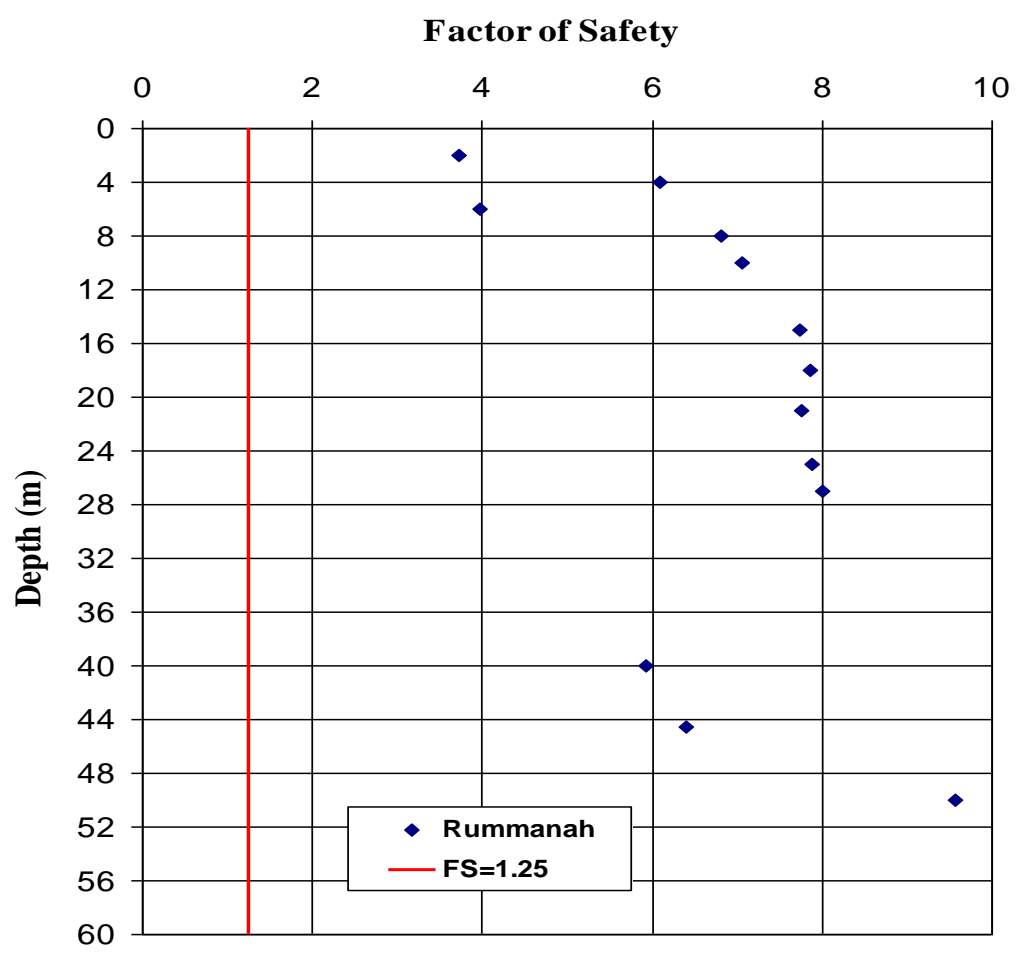

Fig. 8. Safety factors against liquefaction versus depth for Rummanah city.

\subsection{Abu Zenima city}

The studied site is Sinai Manganese Company Complex, which is located at Abu Zenima, south-west Sinai. Six boreholes have been excavated with depths ranging between 10 $\mathrm{m}$ and $25 \mathrm{~m}$, under the site investigation program in this zone. The soil at this site is composed of a top layer of yellowish-brown silty Clay with traces of fine sand / light brown calcareous medium dense Sand \& Gravel with a thickness of about $4.0 \mathrm{~m}$ (with measured 
$\mathrm{N}_{\text {SPT }}$ ranging from 11 to 19 blows) followed by yellowish-brown calcareous medium dense to dense Sand with different percentages of silt (with measured NSPT ranging from 20 to 45 blows) down to the end of the boreholes $(25 \mathrm{~m})$. The groundwater table was found at a depth of about $2.0 \mathrm{~m}$ below the ground surface.

To identify the properties of the sand and silt layer, particle size distribution tests had been carried out and the percentage of fines was ranging from $12 \%$ to $55 \%$. This sand was classified as SM according to the Unified Soil Classification System. The result of the liquefaction analysis is represented in Fig. 9. Using the correlations in item 4.2.1, the factor of safety is more than 1.25 for most depths.

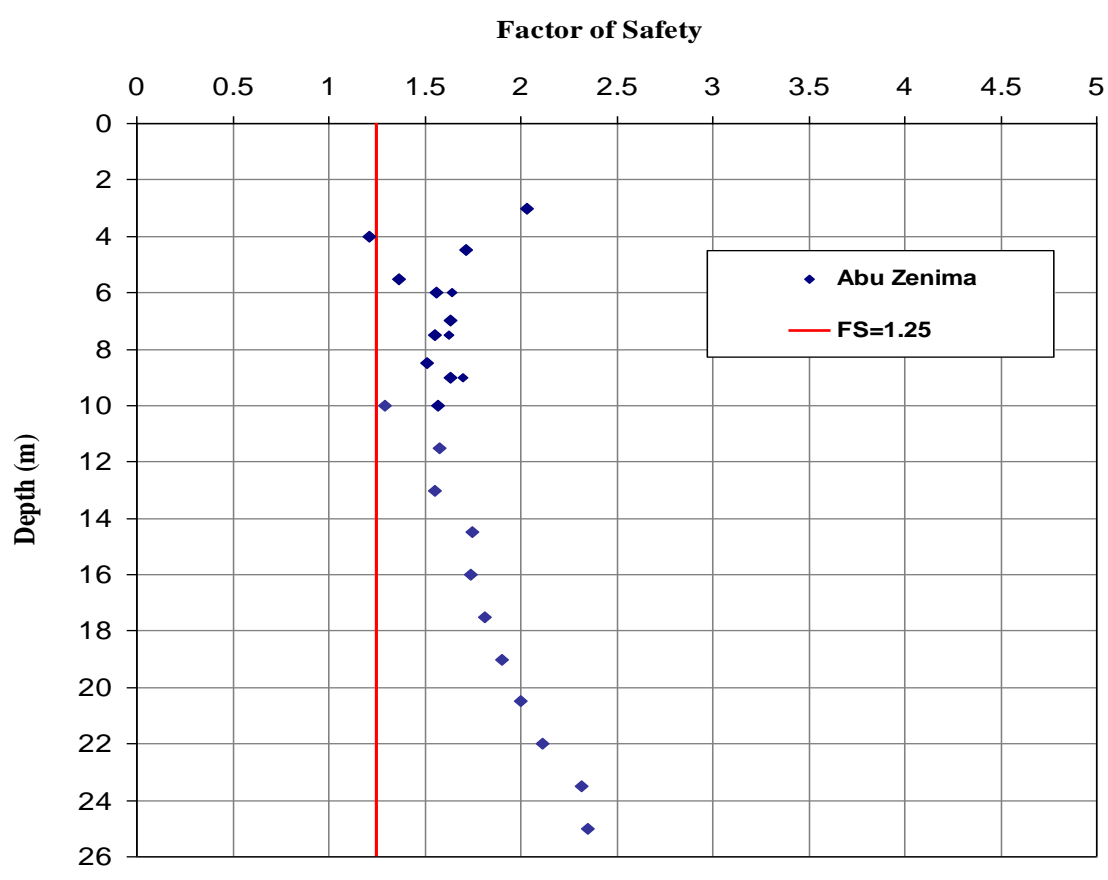

Fig. 9. Safety factors against liquefaction versus depth for Abu Zenima region.

\subsection{Sharm El Shikh city}

The studied site is Al Muntazah Center Project, which is located at Sharm El Sheikh. The soil at this site is composed of an upper medium dense sand layer with some silt and traces of broken shells with a thickness ranging from 4 to $6 \mathrm{~m}$ (with measured $\mathrm{N}_{\mathrm{SPT}}$ ranging from 4 to 34 blows) followed by a middle medium dense to dense sand layer extending down to a depth of 12 to $15 \mathrm{~m}$ (with measured $\mathrm{N}_{\mathrm{SPT}}$ ranging from 12 to 35 blows) followed by a sandy silt layer (with measured $\mathrm{N}_{\mathrm{SPT}}$ ranging from 8 to 26 blows) down to the end of the boreholes $(20 \mathrm{~m})$. The groundwater table was encountered at a depth ranging between $0.6 \mathrm{~m}$ and $1.2 \mathrm{~m}$ below the ground surface.

The variation of the percent of fines and $\mathrm{D}_{50}$ versus depth can be summarized as given in Table 5.

Table 5. Variation of fines content and $\mathrm{D}_{50}$ with depth 


\begin{tabular}{|c|c|c|}
\hline Depth $(\mathrm{m})$ & \% Fines & $\mathrm{D}_{50}(\mathrm{~mm})$ \\
\hline $0.0-5.0$ & 20 & 0.35 \\
\hline 5.0 to $15 \mathrm{~m}$ & 30 & 0.20 \\
\hline 15 to $20 \mathrm{~m}$ & 50 & 0.10 \\
\hline
\end{tabular}

The factor of safety against liquefaction had been plotted versus depth for all boreholes and CRR evaluated using both Seed and Roberston methods for CPT as shown in Figs. 10 and 11 , respectively.

From these results, it can be concluded that the factor of safety for a depth from ground level down to the end of CPT testing is in general higher than 1.0 except for some values which represent loose sand lenses embedded in the silty sand layer.

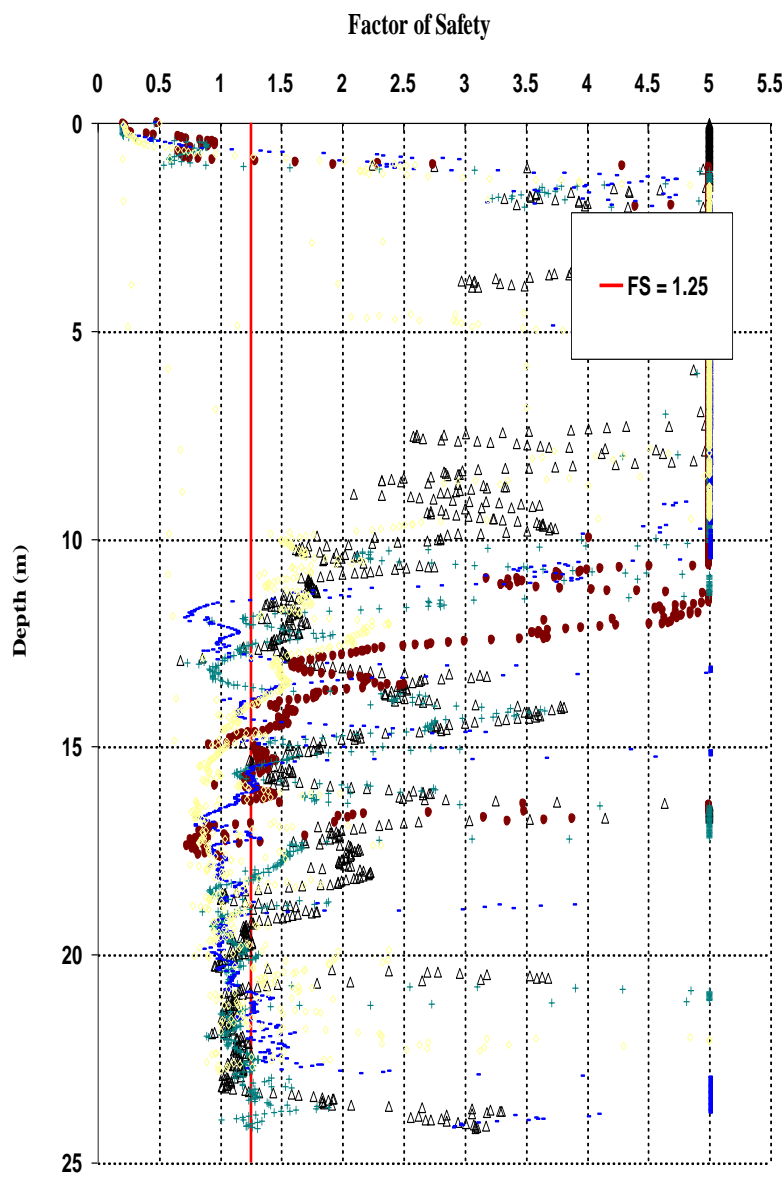

Fig. 10. Safety factors against liquefaction versus depth for Sharm El Sheikh city using Seed method

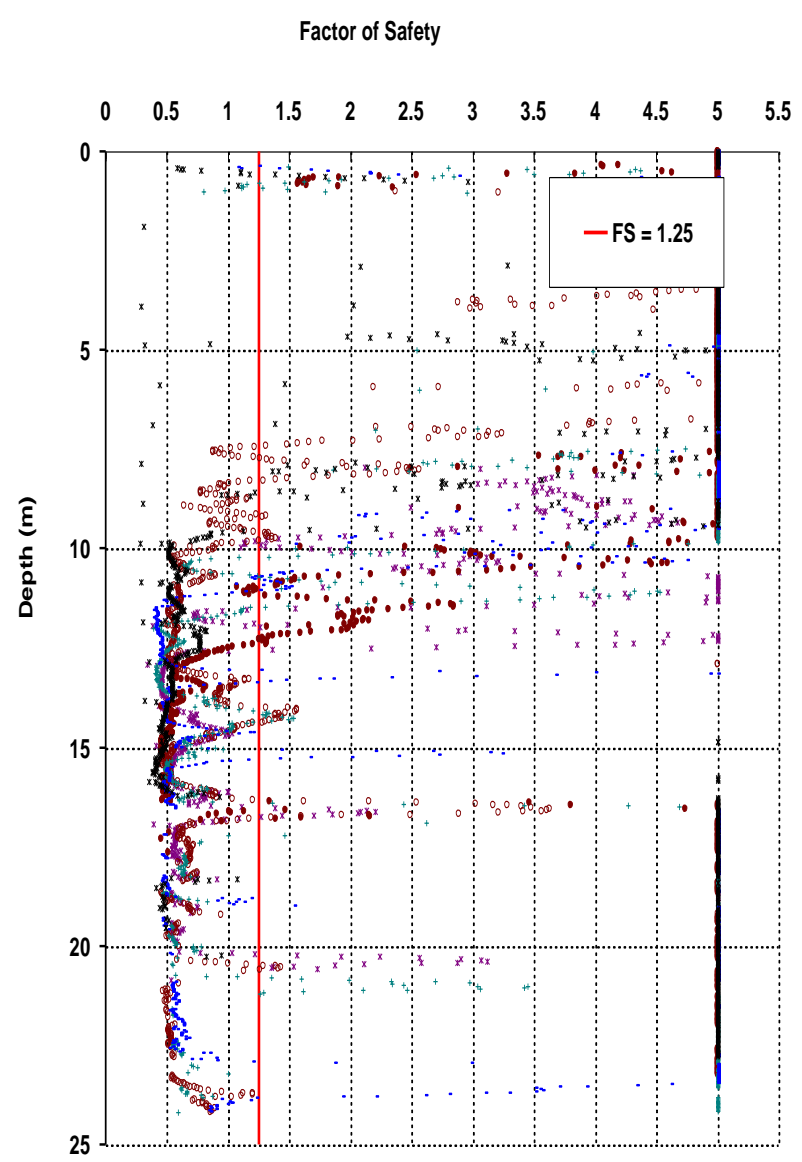

Fig. 11. Safety factors against liquefaction versus depth for Sharm El Sheikh city using Robertson method

\section{MAPPING BASED UPON SAFETY FACTORS AGAINST LIQUEFACTION}

Evaluations of liquefaction susceptibility based on the safety factors are distinguished from site-specific liquefaction evaluations in terms of scope, objectives, and applications. The mapping function approach was first presented by [18]. 
Figure 12 presents the calculated minimum safety factors against liquefaction superimposed in a map of Sinai, producing a map of liquefaction susceptibility. Also, Table 6 summarizes the calculated minimum safety factors of each site. In the approach developed above, analysis using measured SPT or CPT has been used to "calibrate" and confirm the rankings and ratings of liquefaction susceptibility.

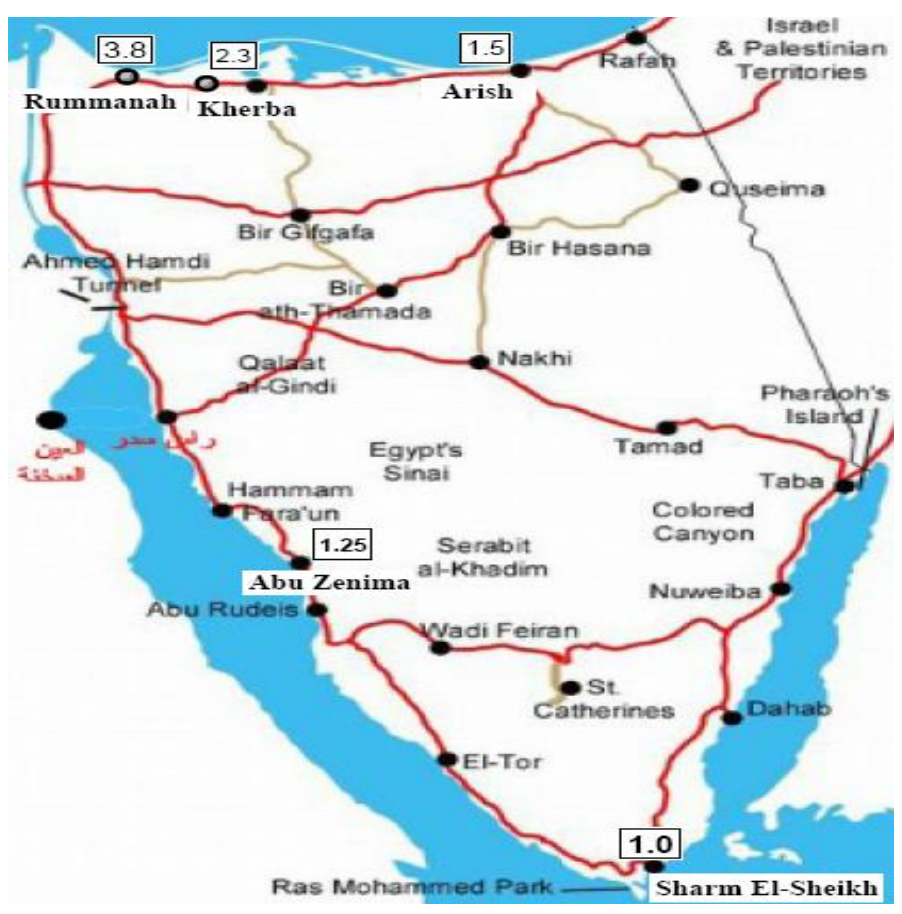

Fig. 12. Map of minimum safety factors against liquefaction for Sinai.

Table 6. The calculated minimum safety factors of each site

\begin{tabular}{|c|c|}
\hline Site & Safety factor \\
\hline RUMMANAH & 3.8 \\
\hline KHERBA & 2.3 \\
\hline ARISH CITY & 1.5 \\
\hline ABU ZENIMA & 1.25 \\
\hline SHARM EL SHEIKH & 1.0 \\
\hline
\end{tabular}

It can be noticed that safety factors have ranged between 1.0 and 3.8. The safety factors seem to be decreased towards the south part of Sinai. The reasons of having Sharm El Sheikh site a low safety factor (1.0) may be because: (1) the ground water level is very near to the ground surface $(0.9 \mathrm{~m})$; (2) the soil layers consists of sand containing a high percentage of non-plastic fines $(20-50 \%)$.

On the other hand, the site of Rummanah (North Sinai) yields high safety factor (3.8) may be because of the following reasons: (1) the ground water level is very deep below ground surface $(16.5 \mathrm{~m})$; (2) the top soil layer containing a low percentage of non-plastic fines $(4-12 \%)$. 
Moreover, this map can potentially provide information leading to more quantitative statements concerning the probability of liquefaction in Sinai zone. This map also provides a framework for interpreting the liquefaction hazard.

\section{CONCLUSIONS}

This study is addressing the liquefaction assessment for some cities in Sinai. The liquefaction potential analysis has been implemented based on the results of both SPT and CPT.

This analysis has showed that very loose silty sand layer is susceptible to liquefaction under the effect of earthquake loading with ground acceleration of $0.2 \mathrm{~g}$. Consequently, the areas of safety factors less than 1.25 (such as Sharm El-Sheikh) must be improved to increase its shear strength. However, the above value of ground acceleration must be checked for the local code of practice and/or project specifications.

This study presents a preliminary map and database of liquefaction susceptibility for some cities located at Sinai region, based on the maximum peak ground acceleration, which had occurred in this region. For geotechnical design, the engineer must decide of the value of the ground acceleration anticipated during the whole project lifetime.

\section{REFERENCES}

1. Seed, H. B., "Soil Problems and Soil Behavior." Robert L. Wiegel, coordinating ed. Prentice-Hall, Englewood Cliffs, NJ, pp. 227-251, 1970.

2. Ishihara, K., "Stability of Natural Deposits During Earthquakes." Proceedings of the Eleventh International Conference on Soil Mechanics and Foundation Engineering, San Francisco, Vol. 1, pp. 321-376, 1985.

3. Said, R., "The Geology of Egypt", Elsevier Publishing Co, Amsterdam and New York, 1962.

4. Maamoun, M., Megahed, A. and Allam, A., "Seismicity of Egypt", Bull of HIAG", Vol. 4B: pp. 109-160, 1984.

5. Qubaissy, R. M., Maamoun, M., Albert, R. N. H. and Megahed, M., "Earthquake Activities and Earthquake Risk around Alexandria, Egypt" Bull. IISEE, Vol. 19, pp. 93-113, 1981.

6. El-Sayed, A., Vaccari, F. and Panza, G.F., "Deterministic Seismic Hazard in Egypt", ICTP, Preprint IC/99/34, Miramare-Trieste, 1999.

7. Deif, A., Abou Elenean, K., El-Hadidy, M., Tealeb, A. and Mohamed, A., "Probabilistic seismic hazard maps for Sinai Peninsula, Egypt", Journal of Geophysics and Engineering, Vol. 6, pp. 288-297, 2009.

8. Salama, A. I., "Seismic Design Criteria for the South Sinai Red Sea rift Zone", International Conference on Earthquake-Resistant Engineering Structures No. 2, Catania, Italia, pp. 415-424, 2001.

9. Moustafa, A.R., "Structural Setting and Tectonic Evolution of North Sinai Folds, Egypt", Geological Society, London, Special Publications, Vol. 341, pp. 37-63, 2010.

10. Shata A.," Structural Development of the Sinai Peninsula, Egypt.", Bull. Inst. Desert Egypt, Vol. 6, No. 2, pp. 117-157, 1956. 
11. Omara, S., “ The Geology of Sharm El-Sheikh sandstone, Sinai, Egypt". Egyptian Journal of Geology, Vol. 3, No. 1, 1959.

12. Seed, H. B., Tokimatsu, K., Harder, L. F., and Chung, R., "Influence of SPT Procedures in Soil Liquefaction Resistance Evaluations." Journal of Geotechnical Engineering, ASCE, Vol. 111, No. 12, pp. 1425-1445, 1985.

13. Stark, T.D. and Olson, S.M., "Workshop: Shear Strength of Liquefied Soil". Geotechnical News, Vol. 16, No. 2, pp. 20-21, 1998.

14. Seed, H. B., "Soil Liquefaction and Cyclic Mobility Evaluation for Level Ground during Earthquakes." Journal of the Geotechnical Engineering Division, ASCE, Vol. 105, No. GT2, pp. 201-255, 1979.

15. Seed, H. B., Idriss, I. M., and Arango, I., "Evaluation of Liquefaction Potential Using Field Performance Data." Journal of Geotechnical Engineering, ASCE, Vol. 109, No. 3, pp. 458-482, 1983.

16. EN 1993 - Eurocode 3

17. Seed, H. B., and Idriss, I. M., "Simplified Procedure for Evaluating Soil Liquefaction Potential." Journal of the Soil Mechanics and Foundations Division, ASCE, Vol. 97, pp. 1249-1273, 1971.

18. Seed, H. B., and De Alba, "Use of SPT and CPT Tests for Evaluating the Liquefaction Resistance of Sands." Proceedings, In Situ 1986, ASCE Specialty Conference on Use of In Situ Testing in Geotechnical Engineering. Special Publication no. 6, ASCE, New York, 1986.

19. Robertson, P.K. and Wride, C.E., "Evaluating Cyclic Liquefaction Potential Using the Cone Penetration Test", Canadian Geotechnical Journal, Vol. 35, No. 3, pp. 442-459, 1998.

20. Proceedings of the NCEER Workshop on Evaluation of Liquefaction Resistance of Soils, NCEER-97-0022, 1997. 